УДК 811.161.2'367.3

Н. П. Литвиненко

\title{
ЛЕКСИКО-СИНТАКСИЧНЕ ВИРАЖЕННЯ ІНТЕНЦЙ ЛІКАРЯ У ПРОФЕСІЙНОМУ МОВЛЕННІ
}

Литвиненко Н. П. Лексико-синтаксичне вираження інтенцій лікаря у професійному мовленні

У статті проаналізовано особливості лексико-синтаксичного вираження інтенцій лікаря під час опитування пацієнта. Виявлено, що з-поміж різних типів речень у структурі реплік-висловлень медичного діалогічного мовлення активністю відзначаються питальні речення тестового характеру, які містять варіанти відповідей альтернативного змісту.

Ключові слова: інтенція, лексико-синтаксичний, тестовий, варіативний, професійний.

Литвиненко Н. П. Лексико-синтаксическое выражение интенций врача в профессиональной речи

В статье проанализированы особенности лексико-синтаксического выражения интенций врача при опросе пациента. Выявлено, что среди различных типов предложений в структуре реплик- 
высказываний медицинской диалогической речи активностью отмечаются вопросительные предложения тестового характера, содержащие варианты ответов альтернативного содержания.

Ключевые слова: интенция, лексико-синтаксический, тестовый, вариативный, профессиональный.

Litvinenko N. P. Lexic-syntactic expression of intentions of doctor in the professional language

The article analyzes the peculiarities of lexical-syntactic expression of intentions physician during patient interviews. It is revealed that among different types of sentences in the structure of the replica-medical statements dialogical speech activity observed interrogative sentence test character, which contain the answers are alternative content.

Key words: intention, lexical and syntactic, test, varied, professional.

Вивчення мови медицини як однієї 3 найдавніших сфер людської діяльності безпосередньо пов'язане з грунтовним аналізом функціонування мови в різних соціальних групах - мовою вчителя [6], мовою політика [7; 8] тощо.

Медична мова - це неоднорідне утворення, у складі якого є жанри, що характеризуються певними соціально-рольовими, комунікативними та структурно-семантичними особливостями [2; 3; 4]. Однією з характерних ознак, що накладає свій відбиток на особливості медичної комунікації, $є$ високий ступінь сугестивності в спілкуванні лікаря з пацієнтом. Ця риса формувала тип стосунків упродовж усієї історії медицини і є визначальною для успішного діагностування та лікування хворої людини. Відповідно впродовж усієї історії медицини формувалися особливі моделі мовленнєвої поведінки, що органічно становлять специфіку медичної комунікації в різних мовних системах. Зважаючи на те, що фахова мова має універсальні та специфічні ознаки і виражається в різних формах спілкування, в межах статті пропонуємо розглянути один із аспектів лексико-синтаксичного вираження інтенцій лікаря у діалогах з пацієнтом на етапі опитування.

Специфіка змістового простору медичної комунікації на цьому етапі відображає особливості концептуалізації дійсності у формі запиту інформації. Опитування зорієнтоване на виявлення основної скарги як провідного симптому, на якому грунтується вся діагностика. Із формальноструктурного погляду це виражено в різновидах питань, що мають граматичні, семантичні та прагматичні відмінності.

Оскільки на цьому етапі метою лікаря є випрацювання гіпотези про стан пацієнта, підтвердження або спростування цієї гіпотези пов'язане 3 відповіддю пацієнта на питання, що містять речення із закритим рядом однорідних членів. Відношення між ними може бути кваліфіковане як розділовий зв'язок взаємоусунення: Біль у Вас колючий чи ріжучий? Судоми бувають зрідка чи постійно? Кожен із членів однорідного ряду називає власне предмет запитання лікаря, що містить певну ознаку. Серед цих ознак найпоширенішою є характеристика больових або тактильних синдромів: Біль стисний чи переймистий? Зуб більше реагує на холодне чи гаряче? Уживаними є запитання щодо психоемоційних відчуттів: Так це у Вас пригніченість чи втома? Частіше Ви відууваєте страх чи збудження? В основі запитання лікаря можуть бути також параметричні 


\section{характеристики стану: Увечері температура підвищується ии} залишається незмінною? Досить поширеною є ознака характеристики вживаних ліків: На Вас краще подіяв траумель-гель чи траумель-мазь? Ескузан Вам виписати в краплях чи пігулках?

Основною ознакою членів однорідного ряду може бути характер реакцій організму на певну процедуру або аналіз: Після зондування Ви почували себе нормально чи було відутття нудоти? Після новокаїнової блокади Вам стало краще чи ні? Лікар може запитувати також про локалізацію симптому чи його хронологічні характеристики: Біль у ділянці пупка чи правіше? Біль з'являеться до вжнивання їжі чи після? Актуальною для лікаря $є$ й інформація про певні епізоди 3 анамнезу пацієнта: Це було діагностичне вишкрібання чи аборт? Вам видалили апендикс вчасно чи був перитоніт?

Такі речення мають варіанти відповідей, за допомогою яких уточнюють симптоми, про які надто загально або не досить чітко повідомляє пацієнт. Лікар у своєму питанні називає всі відомі $з$ клінічної картини прогнозованого захворювання ознаки чи характеристики симптому, можливі епізоди анамнезу. У будь-якому разі, відповідаючи на питання лікаря, пацієнт має змогу вибрати найбільш прийнятий для нього варіант відповіді з-поміж декількох запропонованих.

У діалогах, які відбуваються під час першого звертання пацієнта до лікаря, такі речення досить поширені. Вони становлять основу лікарського опитування для визначення попереднього діагнозу та обрання напрямку подальшого обстеження. Використання саме такої моделі для опитування дає змогу точно сформулювати питання, визначити конкретний аспект очікуваної відповіді. Порівняймо дві моделі питального речення: Який Ви вживаєте інсулін? - Ви вживаєте вітчизняний інсулін чи закордонний? У першому реченні питання сформульовано не досить чітко. Щоб відповісти на нього, пацієнтові доводиться внутрішньо з'ясовувати для себе, що має на увазі лікар, тобто визначити аспект запитання. Нечіткість формулювання пов'язана з семантичною абстрактністю займенника який, що може вказувати на будь-яку ознаку. У другому реченні, коли питання формулюється як пропозиція обрати одну 3 альтернативних відповідей, пацієнт має змогу точно зрозуміти питання лікаря, зосередити увагу на релевантних для діагностування симптомах та адекватно відповісти.

Аналізовані питальні речення - це своєрідний тест, який вибудовує лікар для охоплення всієї сукупності симптомів із парадигмами їхніх видозмін під впливом певних чинників. Після такого питання та відповіді пацієнта, обраної із запропонованої альтернативи, логічно 3'являється наступне питання лікаря, поява якого мотивується відповіддю пацієнта. Якби відповідь пацієнта була іншою, то й наступне питання було б іншим. Порівняймо два діалоги:1. Лікар: У Вас короткозорість вроджена чи набута? Пацієнт: Набута. Лікар: Із якого віку? Пацієнт: Із двадияти років. 
2. Лікар: $У$ Вас короткозорість вроджена чи набута? Пацієнт: Вроджена. Лікар: Хтось із батьків страждав нею? Пацієнт: Так, батько.

Як бачимо, в обох діалогах логіка опитування спрямована на те, щоб відповідь пацієнта була конкретною і достатньою для отримання потрібної інформації про його стан здоров'я. Досягнення цієї мети забезпечує можливість формулювання наступних питань лікаря як безальтернативних речень. У першому діалозі такою метою $є$ визначити період перебігу захворювання, зокрема iї початок, у другому - характер захворювання (спадкова чи набута).

Альтернативні відповіді в запитанні містять здебільшого дві протиставлені частини, із яких пацієнт має вибрати одну для відповіді: Коли з'являється кашель: удень чи вночі? Яке мокротиння відкашлюєте: рідке чи в'язке? Якого кольору мокротиння: прозоре чи жсовто-зелене?

Поширеними $є$ також альтернативні питання, які складаються більше ніж із двох протиставлених частин: Коли у Вас буває нудота: після вживання їжі, до вживання ӥжі чи постійно? У такому разі розділовий сполучник чи виконує роль своєрідного сигналу про те, що названі симптоми перебувають у відношеннях взаємного заперечення, тому пацієнт повинен обрати лише одну відповідь 3-поміж усіх запропонованих.

Серед альтернативних питань натрапляємо на такі, які можна було б назвати питаннями з нечітко вираженою альтернативою. Лікар називає ряд можливих симптомів, не вживаючи між ними розділового сполучника: Який біль відчуваєте в сериі: пекучий, тупий, гострий? У таких випадках ряд означень $є$ відкритим. Лікар називає найпоширеніші з характеристик типів болю, хоч можливі й інші. Елемент підказки в питанні лікаря допомагає пацієнтові зорієнтуватися, зрозуміти мету лікаря і водночас залишитися достатньо самостійним у визначенні симптому. Ці симптоми називає лікар, однак вибрати один із них як найбільш вдалий має сам пацієнт, що допомагає йому подолати комунікативні труднощі у процесі вербалізації своїх фізичних відчуттів та психосоматичних ознак.

Питальні речення, уживані лікарем, можуть бути побудовані за двома моделями: питальні речення нетестового характеру та питальні речення тестового характеру. Названі моделі мають неоднакові можливості для досягнення лікарем комунікативної мети. Наприклад, питання про виробника певного медичного препарату може мати як нетестовий (Який Ви вживаєте диклофінак?), так і тестовий характер (У Вас диклофінак вітчизняний чи німещький?). Для питальних речень нетестового характеру властива нечіткість у формулюванні комунікативної мети. Вони передбачають відповіді різного тематичного наповнення: виробник препарату, агрегатний стан (рідина, суспензія, таблетки тощо), спосіб застосування (ентеральний, парантеральний та ін.).

Моделі тестового характеру відзначаються чіткістю, конкретністю i змістовно орієнтовані: $B u$ вживаєте диклофінак вітчизняний чи 
імпортний? Ви вживали диклофінак в таблетках чи суспензію? Вам раніше призначали ін 'єкцї диклофінаку чи таблетки?

Другу модель питальних речень уважаємо найбільш прийнятною для мовлення лікаря і пояснюємо тим, що речення тестового характеру дають змогу лікареві конкретніше висловити свою комунікативну потребу в репліках-висловленнях, адресованих пацієнту. Водночас зауважимо, що такі речення не є однорідними за змістом і за граматичною структурою. Так, зокрема, однорідні члени в питальних реченнях можуть бути поєднані безсполучниковим, сполучниковим та мішаним зв'язком.

У разі використання безсполучникового зв'язку альтернатива в запитанні не досить чітко визначена: Біль у Вас тупий, гострий, переймистий? Ви краще себе почуваєте зранку, в середині дня, ввечері? Речення з таким видом зв'язку трапляються зрідка.

Сполучниковий зв’язок представлений розділовим сполучником чи. У мовленні лікаря-фахівця зафіксовано різні за структурою ряди однорідних членів 3 розділовими сполучниками. Частіше він ставить питання 3 двома протиставленими варіантами відповідей, що поєднуються неповторюваним розділовим сполучником чи, у яких пацієнтові запропоновано альтернативну відповідь на поставлене питання: Задуха зникає сама по собі чи після зменшення фізичного навантаження? Біль з'являсться одразу після вживання гострої їжі чи пізніше? Біль у Вас постійний чи нападоподібний? Шумить частіше в лівому вусі чи в правому? Значно менше питальних речень 3 повторюваним розділовим сполучником чи...чи, який уживається перед кожним з однорідних членів: Біль у Вас виникає частіме де: чи в епігастральній ділянці, чи в правому niдребер $\dddot{\imath}$, чи в лівому? Такий вид поєднання однорідних членів буває досить рідко, тому що використання повторюваного сполучника робить речення надто громіздким, що ускладнює сприймання пацієнтом висловлення лікаря.

Повторюваний розділовий сполучник чи...чи іноді вживають перед кожним із однорідних членів, крім першого: Коли Ви відкашлюєте мокротиння: увечері, чи вранщі, чи впродовж дня? Таке вживання сполучника чи дає змогу лікареві-мовцеві чітко розмежовувати можливі симптоми, завдяки чому він може розраховувати на адекватну відповідь.

Значно частіше використовують у таких питальних реченнях мішаний зв'язок, зокрема той його різновид, коли сполучник ии вживається лише перед останнім членом однорідного ряду: Якого характеру біль у діляниі серцяя Вас турбує: стискальний, стисний, колючий чи гострий? Одноразове вживання сполучника чи спостерігаємо тоді, коли перелік параметрів стану пацієнта в питанні лікаря $\epsilon$ вичерпаним і однорідний ряд не може бути продовженим. У такому разі пацієнтові залишається вибрати одну із запропонованих відповідей, зіставивши свій стан здоров'я із закритим переліком симптомів. 
Розділовий сполучник чи у питальних реченнях тестового характеру може вживатися хаотично, перед будь-яким членом ряду, крім останнього: У Вас були які-небудь ознаки застуди: камель, чи нежить, біль у горлі? Таке вживання можливе тоді, коли однорідний ряд $\epsilon$ відкритим, як ми це спостерігаємо в наведеному прикладі: названо не всі ознаки застуди, тому ряд однорідних членів може бути продовжений. Ці питальні речення мовець будує спонтанно, начебто пригадуючи в процесі мовлення можливі ознаки, i приєднує кожну згадану ознаку до попередньо названих за допомогою розділового сполучника чи або без нього. Варіювання місця розділового сполучника вносить до речення додаткову семантику приєднання, про що в науковій літературі зазначено: «Варіювання складників сполучника або сполучникового поєднання, або повторення сполучника, тільки починаючи 3 другого члена ряду, можна використовувати для вираження додаткових значень: послідовності, градації, обмеження, додавання, приєднання, оцінки» [5, с. 172].

У таких питальних реченнях значення взаємного заперечення виявляє себе досить своєрідно, оскільки відповідей може бути більше, ніж одна: в аналізованому реченні - це кашель, нежить і біль у горлі. Відмінність у значеннях однорідних членів нівелюється, а отже, сполучник може бути опущений без будь-яких утрат змісту. Пор.: У Вас були якінебудь ознаки застуди: кашель, чи нежить, біль у горлі? - У Вас були якінебудь ознаки застуди: кашель, нежить, біль у горлі? У таких відкритих рядах лікар називає ознаки, які, за його припущенням, можуть бути в пацієнта, тому доцільно вводити до речення вставне слово із семантикою припущення: У Вас є проблеми з опорно-руховою системою - біль у колінах, можливо, у хребті, біль у суглобах? Так само в згаданому вище прикладі: У Вас були які-небудь ознаки застуди: камель, можливо, нежить, біль у горлі?

Питальні речення 3 рядами однорідних членів, поєднаних

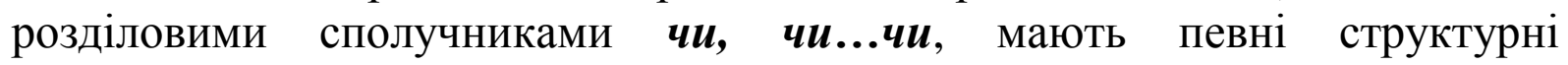
особливості. Досить часто вони містять узагальнювальне слово, яке передує рядові однорідних членів: У якій ділянці з'являється біль: лобній, тім'яній чи в потиличній? Функцію узагальнювального слова може

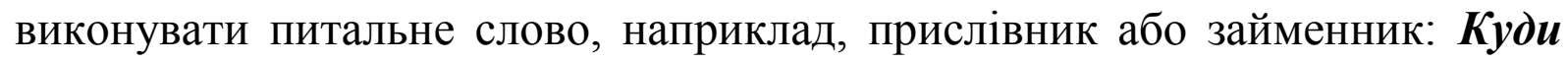
віддає біль: у праве плече, під лопатку чи в шию? Що Ви зараз відчуваєте: біль чи поколювання? Який у Вас біль: судомний чи коліка? У таких реченнях спостерігаємо певні особливості послідовності слів: однорідні члени стоять завжди після узагальнювального слова i розташовані здебільшого дистантно: Що Ви відчуваєте в роті: сухість чи гіркоту? Буває, що узагальнювальне слово, якщо воно виражене непитальним словом, стоїть безпосередньо перед однорідними членами: Вам надавали вдома першу допомогу: викликали блювоту чи промивали шлунок? Можливі й експресивні комунікативні варіанти цього ж речення: Першу 
допомогу Вам удома надавали? Вам першу допомогу вдома надавали? Якщо узагальнювальне слово є питальним, то воно виступає на початку речення: Коли Ви відчуваєте біль у горлі: постійно чи під час ковтання?

Нерідко лікар намагається актуалізувати узагальнювальне слово, указати на його зв язок із наступним рядом однорідних членів. У такому разі змінюється послідовність слів i питальне слово, яке $є$ водночас узагальнювальним, переміщується 3 початку речення в позицію перед однорідним рядом: Біль відчуваєте де: у суглобах, у хребті чи в попереці? Головний біль починається коли: із самого ранку чи ближче до полудня? Переміщення питального слова $є$ одним із мовних засобів реалізації лікарем своїх фахових потреб: актуалізуючи питальне слово, мовець-лікар спрямовує мовленнєву діяльність пацієнта. У такому питальному реченні думку виражено експліцитно, тому мовцеві-пацієнтові доведеться зробити вибір із запропонованих альтернатив. Лікар, вибудовуючи гіпотезу, зосереджує увагу мовця-пацієнта на його відчуттях (больових, тактильних, психоемоційних) i спонукає його до точного визначення локалізації симптомів, їхнього характеру й особливостей перебігу, змін у стані тощо.

Запитання тестового характеру в аналізованому дискурсі можуть мати структуру не лише простого речення з рядами однорідних членів, а й складного, зокрема складносурядного розділового речення: Біль зникає сам по собі чи Вам треба вживати ліки? У науковій літературі такі речення вважають складносурядними, семантичну основу яких «становлять повідомлення про несумісність або чергування явищ» [1, с.303]. Уживаючи ці речення, лікар має ширші можливості для опитування, оскільки він тестує стан пацієнта за кількома параметрами або з'ясовує наявність зв'язків між симптомами: Головний біль з 'являється сам по собі, чи він пов'язаний з болем у правому підребер '̈??

Трапляються складні речення, що містять дві предикативних частини, які чітко визначають альтернативу: Поява болю пов'язана зі споживанням їжі, чи коліка з'являсться у будь-який час? Деякі складні речення мають більше ніж дві предикативних частини: Напад печінкової коліки супроводжується відчуттям холоду, Вас лихоманить, чи Ви відчуваєте загальну слабкість? Такі речення здебільшого ускладнені підрядними частинами, тобто за структурою $є$ складними реченнями 3 різними видами зв'язку: Біль має тупий характер, він нападоподібний, чи біль, як коліка, чи так, наче ріже хтось ножем? Найчастіше до таких складних речень уводяться підрядні порівняльні.

Уведення підрядних порівняльних частин сприяє точності у з'ясуванні та констатації наявних симптомів захворювання. Удаючись до припущень, лікар пропонує пацієнтові зосередитися на одному з варіантів у характеристиці ознаки свого загального фізичного стану. Ідеться про реалізацію пропозиційногіпотетичної тактики на етапі системного опитування у контексті з'ясувально-констатаційної стратегії. 
Ще одним засобом реалізації фахових потреб лікаря є вживання ним такого різновиду питальних речень, визначальною рисою яких $\epsilon$ окремі уточнення наданої пацієнтом інформації. Лікар: Коли Ви піднімаєтеся сходами, у Вас буває задуха? Пацієнт: Мені важко підніматися. Я просто задихаюся. Лікар: Тобто Ви змушені зробити перепочинок, потім можете знову підніматися, так?

Як бачимо, ідеться про те, що, спираючись на фахові знання і досвід, лікар здатний прогнозувати появу певних симптомів чи змін у стані пацієнта за допомогою реченьприпущень. Такі речення зазвичай містять пропозицію відновити пропущені ланки в розповіді пацієнта. За формою ці речення є питальними, оскільки лікар, гіпотетично оцінюючи стан пацієнта, все ж пропонує йому підтвердити або спростувати свої припущення. Здебільшого пацієнт реагує ствердно, а в багатьох випадках розвиває думку лікаря, що вносить завершальні елементи в характеристику його стану. Отже, припущення, зроблене лікарем, та пропозиція підтвердити його стимулює пацієнта до розгортання точного й повного опису симптомів захворювання. Такі питальні речення заохочують пацієнта до розмови, що є найбільш актуальною комунікативною метою лікаря на етапі опитування.

Речення 3 елементами уточнення побудовані здебільшого як складнопідрядні з підрядним умови або часу. Наприклад: Лікар: Цей зуб турбує Вас давно? Пацієнт: Близько двох місящів. Ну, не часто так, не регулярно, від випадку до випадку. Лікар: У Вас там випала пломба, так? Пацієнт: Так, так. Лікар: I потім він Вас турбував тільки тоді, коли потрапляла туди ӥжса, так?

Можлива й інша будова питальних речень з елементом уточнення. Це складносурядне або безсполучникове складне речення, частини якого, повідомляючи про послідовність певних дій, відтворюють в уявленні лікаря картину захворювання: Лікар: У Вас випала пломба? Пацієнт: Так, так. Лікар: Зуб Вас турбує? Реагує на холодне чи гаряче? Пацієнт: Може, на холодне іноді. Ще коли я їла, накусувала на нього, тоді він...Лікар: Отюже, Ви їсте, в порожнину рота потрапляе ӥжа, і Ви відчуаєте біль, так?

Лікар запитує пацієнта, чи насправді це так, тому обов'язковим елементом речення є питальне слово так: Лікар: Де Ви відчуваєте біль? Пацієнт: Внизу живота. Коли починаються місячні, дуже сильний біль. Лікар: А в інші дні біль Вас турбує? Пацієнт: В інші - ні. Лікар: Тобто низ живота болить тільки в період місячних, так? Іноді лікар нібито заступає собою пацієнта, починаючи розповідати замість нього. Лікар: Розкажіть мені, будь ласка, про свій ранок: коли Ви прокидаєтесь вранці, Ви маєте гіркоту в роті, так? Пацієнт: Так, сухість, гіркоту.

Завдяки опитуванню пацієнта в такий спосіб, лікар скеровує його розповідь, стимулюючи до виокремлення симптомів, що допомагають правильно визначити діагноз. Пацієнт, підтверджуючи або спростовуючи 
припущення лікаря, адекватно продовжує опис свого стану: Лікар: Із самого ранку болить голова, так? Пацієнт: Так, найчастіше болить зранку, але інколи й пізніше.

За комунікативною метою ці речення своєрідні - у них міститься як ствердження, так і запитання, але саме у формі розповідного речення лікар повідомляє зміст свого припущення, щоб потім за допомогою питального слова «так» перевірити його достовірність, тотожність стану пацієнта.

Отже, на етапі опитування, регламентованому традиційними схемами діагностичного процесу, лікар виступає комунікативним лідером, вибудовуючи методику спілкування залежно від особливостей комунікативної взаємодії з пацієнтом. 3-поміж різних типів речень, що формують структуру висловлень у діалогічному мовленні лікаря, активністю відзначаються питальні речення тестового характеру, які містять варіанти відповідей альтернативного змісту. Цей мовний прийом реалізується в питальних реченнях з різними типами зв'язку. особливістю будови яких є наявність у них закритого ряду однорідних членів. Найбільш поширеним $є$ мішаний зв 'язок, зокрема той його різновид, коли сполучник уживають перед останнім членом ряду. Такому ряду однорідних членів може передувати узагальнювальне слово, яке завдяки своїй абстрактній семантиці вказує на узагальнену назву предмета запитання. Речення тестового характеру виявляють себе також у стверджувально-питальних конструкціях, які містять уточнення щодо повідомлюваних пацієнтом симптомів i доповнюють його інформацію 3 огляду на припущення, зроблені лікарем. Усе це допомагає пацієнтові подолати комунікативні труднощі у вербальному вираженні своїх фізичних відчуттів та психосоматичних ознак.

\section{Література}

1. Вихованець I. Р. Граматика української мови. Синтаксис : Підручник / I. Р. Вихованець. - К. : Либідь, 1993. - 368 с.

2. Иванчук И. А. Культура речи в деятельности врача (к проблеме формирования элитарного типа языковой личности в профессиональной медицине) / И.А. Иванчук // Вопросы стилистики. - Саратов, 1998. - С. $187-195$.

3. Литвиненко Н. П. Український медичний дискурс : [монографія] / Н. П. Литвиненко - Х. : Харківське історико-філологічне товариство, 2009. - 304 с.

4. Миллз М. Коммуникативный анализ медицинского профессионального общения «врач пациент» / М. Миллз // Русский язык сегодня : сб. статей. Отв. ред. Л. П. Крысин. - М. : Азбуковник, 2000. - Вып. 1. - С. $342-349$.

5. Русская грамматика : в 2-х т. - М. : Наука, 1980. - Т. 2. - 709 с

6. Струганець Л. В. Культура української мови і мовна особистість учителя : автореф. дис. на здобуття наук. ступеня канд. філол. наук. : спец. 10.02.01 «Українська мова» / Л. В. Струганець. - К., 1996. -22 c.

7. Чудинов А. П. Метафорическая мозаїка современной политической коммуникации / А. П. Чудинов. - Екатеринбург, 2003. - 156 с.

8. Шейгал Е. И. Семиотика политического дискурса / Е. И. Шейгал. - Волгоград, 2000. 